\title{
INTEGRASI FONOLOGI BAHASA MINANGKABAU DALAM BAHASA MELAYU BENGKULU
}

\section{PHONOLOGY INTEGRATION MINANGKABAU LANGUAGE IN BENGKULU MALAY LANGUAGE}

\author{
Syamsurizal \\ Kantor Bahasa Bengkulu \\ syamsurizal1966@yahoo.com
}

\begin{abstract}
ABSTRAK
Tulisan ini bertujuan mendeskripsikan integrasi fonologi bahasa Minangkabau dalam bahasa Melayu Bengkulu dalam persepsi sosiolinguistik. Metode yang digunakan dalam penelitian ini adalah metode deskriptif. Data dikumpulkan dengan menggunakan metode simak, dengan teknik dasar berupa teknik sadap, teknik simak bebas libat cakap dan teknik catat. Penyimakan dilakukan dengan menyadap penggunaan bahasa dalam "Komunitas Belungguk Baso Bengkulu". Berdasarkan hasil analisis data, diperoleh integrasi bahasa Minangkabau dalam bahasa Melayu Bengkulu meliputi aspek fonologi. Integrasi fonologi dapat berupa penghilangan fonem (pada awal, tengah, dan akhir), misalnya [acok] [cok] 'sering' [antok] [ntok] 'diam'[jagok] [jgok] 'pintar' [ateh][ate] 'atas'; penambahan fonem, misalnya [angik] [anggit] 'bau apek' [mada] [madal] 'keras kepala'; atau melalui proses perubahan fonem yaitu /a/ menjadi /e/, misalnya [mancalik] [mencelik]'melihat', [marapek] [merapek] 'merapat', /u/ menjadi /o/, misalnya [urang gaek] [orang gaek] 'orang tua', /u/ menjadi /e/, misalnya [gulamo] [gelamo] 'nama ikan', /ui?/ menjadi /ut/, misalnya [kambuik] [kambut] 'tas anyaman pandan'.
\end{abstract}

Kata Kunci: Integrasi fonologi, bahasa Minangkabau.

\section{ABSTRACT}

This paper aims to describe the integration of the phonology of the Minangkabau language in the Bengkulu Malay language in sociolinguistic perceptions. The method used in this research is descriptive method. Data were collected using the listening method, with the basic techniques in the form of tapping techniques, free engages involved in competent listening and note taking techniques. The listening is done by tapping into the use of language in the "Belungguk Baso Bengkulu Community". Based on the results of data analysis, the integration of the Minangkabau language in Bengkulu Malay includes phonological aspects. Phonological integration can take the form of phonemes (at the beginning, middle and end), for example [acok] [cok] 'often' [antok] [ntok] 'silent' [jagok] [jgok] 'smart' [ateh] [ateh] 'on'; phoneme additions, for example [angik] [anggit] 'musty smell' [mada] [madal] 'stubborn'; or through the process of changing phonemes ie / a / to / e /, for example [mancalik] [mencelik] 'seeing', [marapek] [merapek] 'docked', / u / being / o /, for example [urang gaek] [orang gaek] 'old man', / u / be / e /, for example [gulamo] [gelamo] 'fish name', / ui? / become / ut /, for example [kambuik] [kambut] 'pandan woven bag'.

Keywords: Phonological integration, Minangkabau language. 


\section{PENDAHULUAN}

Masyarakat Kota Bengkulu adalah masyarakat tutur yang terbuka dan heterogen. Di sini terdapat penduduk asli Bengkulu, seperti suku Melayu Bengkulu, suku Lembak, suku Rejang, Enggano, Serawai, Pekal, Pasemah, serta beberapa suku pendatang, seperti Jawa, Bugis, Batak, Bali, dan Minangkabau. Untuk berkomunikasi dan berintegrasi dengan masyarakat yang berbeda etnis dengan mereka, suku Melayu Bengkulu menggunakan bahasa Melayu Bengkulu sebagai bahasa pengantar, di samping menggunakan bahasa Indonesia. Bahasa Melayu Bengkulu adalah salah satu bahasa daerah di Provinsi Bengkulu yang dituturkan oleh suku Melayu Bengkulu yang mendiami wilayah sekitar Kampung Pondok, Penurunan, Kebun Kenanga, Kebun Beler, dan di sepanjang wilayah pantai Kota Bengkulu.

Keterbukaan suku Melayu Bengkulu ini menyebabkan mereka tersentuh oleh masyarakat tutur lain. Akibatnya, terjadilah kontak bahasa antara suku Melayu Bengkulu dengan masyarakat tutur lain dengan segala peristiwa kebahasaannya. Peristiwa kebahasaan yang timbul akibat kontak bahasa itu misalnya bilingualisme atau kedwibahasaan atau multibahasa, diglosia, alih kode, campur kode, konvergensi, pergeseran bahasa, interferensi bahasa, dan integrasi bahasa.

Integrasi bahasa adalah penggunaan unsur-unsur bahasa lain oleh suatu bahasa dan dianggap sudah menjadi bagian dari bahasa tersebut, serta tidak dianggap sebagai unsur pinjaman atau pungutan lagi (Mackey, 1968 dalam Chaer dan Agustina 2010:128). Integrasi bahasa Minangkabau merupakan gejala kebahasaan yang terjadi akibat adanya penggunaan bahasa Minangkabau dalam suatu peristiwa komunikasi antara suku Minangkabau dengan suku Melayu Bengkulu., terutama dalam bahasa lisan. Penggunaan unsur bahasa Minangkabau ke dalam bahasa Melayu Bengkulu ini di satu sisi dianggap sebagai suatu kesalahan, karena terjadi penyimpangan kaidah atau aturan dari bahasa yang digunakaan. Sementara di sisi lain, integrasi tidak dianggap sebagai suatu penyimpangan, karena unsur-unsur bahasa donor telah disesuaikan dengan bahasa sasaran dan dianggap sebagai kosakata baru oleh bahasa sasaran. Hal ini sesuai dengan yang dikatakan Kridalaksana (1998:84), bahwa integrasi adalah penggunaan unsur bahasa lain secara sistematis seolah-olah merupakan bagian dari suatu bahasa tanpa disadari oleh pemakainya. Integrasi adalah penyerapan kata-kata suatu bahasa ke dalam bahasa lain.

Penelitian tentang integrasi suatu bahasa ke dalam bahasa yang lain bukanlah penelitian terbaru. Sebelumnya telah banyak penelitian yang dilakukan oleh para ahli dan peneliti lain. Di antaranya adalah penelitian yang disusun oleh Saharuddin tentang "Interferensi Bahasa Bugis Terhadap Penggunaan Bahasa Indonesia di Pasar Tradisional Desa Sioyong, Kabupaten Donggala". Dalam penelitiannya, Saharuddin menyimpulkan bahwa pemakaian bahasa Indonesia para pedagang dan pembeli di pasar tradisional Desa Sioyong, Kabupaten Donggala diwarnai oleh interferensi bahasa Bugis. Bentuk-bentuk interferensi bahasa Bugis itu meliputi; (1) interferensi fonologi, (2) interferensi morfologi, dan (3) interferensi sintaksis. 
Tuah Talino

Tahun XIII Volume 13 Nomor 1 Edisi 5 Juli 2019

ISSN 0216-079X

Balai Bahasa Kalimantan Barat

Penelitian tentang integrasi bahasa Minangkabau ke dalam bahasa Melayu Bengkulu sepengetahuan peneliti belum pernah dilakukan. Oleh sebab itu, cukup menarik bagi peneliti untuk mengkaji integrasi bahasa Minangkabau ke dalam bahasa Melayu Bengkulu ini. Masalah dalam penelitian ini adalah bagaimana bentuk integrasi fonologi bahasa Minangkabau dalam bahasa Melayu Bengkulu? Sesuai dengan pertanyaan penelitian, penelitian ini bertujuan mendeskripsikan bentuk integrasi fonologi bahasa Minangkabau dalam bahasa Melayu Bengkulu.

Data penelitian ini adalah tuturan bahasa Melayu Bengkulu yang terdapat dalam grup facebook Komunitas Belungguk Baso Bengkulu. Diharapkan penelitian bermanfaat dalam mengungkapkan asal-usul bahasa atau suku Melayu Bengkulu.

\section{Interferensi Bahasa}

Pada awalnya, masuknya bahasa asing ke dalam bahasa Indonesia banyak dilakukan secara audial. Artinya, mula-mula penutur bahasa Indonesia mendengar butir-butir leksikal bahasa asing itu dituturkan oleh penutur aslinya, lalu mencoba menggunakannya (Chaer dan Agustina, 2010:128). Apa yang terdengar oleh telinga, itulah yang diujarkan, kemudian dituliskan. Oleh sebab itu, kosakata yang diterima secara audial seringkali menampakkan ciri ketidakteraturan bila dibandingkan dengan kosakata aslinya. Demikian pula halnya dengan masuknya bahasa Minangkabau ke dalam bahasa Melayu Bengkulu. Mula-mula penutur bahasa Melayu Bengkulu mendengar butir-butir leksikal bahasa Minangkabau dituturkan oleh penutur aslinya, lalu mereka coba untuk menggunakannya. Semua yang terdengar oleh telinga mereka, kemudian mereka ujarkan, lalu mereka tuliskan. Sebagai contoh misalnya kata barek 'berat' (BM) diserap menjadi brek 'berat', lapeh 'lepas' menjadi lpe 'lepas', kabek 'ikat' menjadi kebat 'ikat', bareh 'beras' menjadi breh, dan sebagainya.

Dari beberapa contoh di atas terlihat bahwa dengan masuknya sistem suatu bahasa ke dalam bahasa lain, terjadilah penyimpangan penggunaan bahasa. Peristiwa penyimpangan norma dari satu bahasa atau lebih ini oleh Chaer dan Agustina (1995:168) disebut dengan interferensi. Interferensi terjadi karena kebiasaan si penutur dalam berkomunikasi menggunakan bahasa daerahnya dalam kehidupan sehari-hari.

Khak (1985:8) dengan mengacu pada pendapat Valdman (1966) menyatakan bahwa interferensi merupakan hambatan, akibat kebiasaan si pemakai bahasa ibu (bahasa pertama) memasukkan bahasa ibu (bahasa pertamanya) dalam berkomunikasi dengan bahasa yang dipelajarinya (bahasa kedua). Sebagai konsekuensinya, terjadilah transfer atau pemindahan unsur negatif dari bahasa ibu (B1) ke dalam bahasa sasaran (B2).

Interferensi dianggap sebagai sebuah kesalahan, karena terjadi penyimpangan norma/kaidah atau aturan dari bahasa yang digunakan (Saharuddin, 2016:70). Walaupun interferensi pada satu sisi adalah sebuah kesalahan, karena dapat "merusak" sistem suatu bahasa, tetapi pada sisi lain, interferensi dipandang sebagai suatu mekanisme yang paling penting dan dominan untuk mengembangkan suatu bahasa yang masih perlu pengembangan, terutama pada subsistem kosakata dan semantik, sebagaimana halnya bahasa Melayu Bengkulu ini. Dengan interferensi, kosakata bahasa resepien menjadi diperkaya 
Tuah Talino

Tahun XIII Volume 13 Nomor 1 Edisi 5 Juli 2019

ISSN 0216-079X

Balai Bahasa Kalimantan Barat

oleh kosakata bahasa donor, yang pada awalnya dianggap sebagai pinjaman, tetapi kemudian tidak lagi, karena telah terintegrasi menjadi bagian dari bahasa resepien (Chaer dan Agustina, 2010:128).

\section{Integrasi Bahasa}

Beda dengan interferensi, integrasi adalah digunakannya unsur-unsur suatu bahasa ke dalam bahasa lain secara sistematis, dan seolah-olah merupakan bagian dari suatu bahasa tersebut tanpa disadari oleh si pemakainya (Kridalaksana, 1998:84). Salah satu proses integrasi adalah "peminjaman" kosakata suatu bahasa ke dalam bahasa lain. Sebagian sosiolinguis berpendapat bahwa masalah integrasi sulit dibedakan dari interferensi karena sama-sama adanya penyimpangan bahasa. Namun, kita bisa membedakannya, yaitu interferensi masih dalam proses, sementara integrasi sudah menetap dan diakui sebagai bagian dari bahasa penerima.

Senada dengan pendapat di atas, Chaer dan Agustina (2010:128) dengan mengacu pada pendapat Mackey (1968), menyatakan bahwa integrasi adalah digunakannya unsur-unsur bahasa lain dalam suatu bahasa tertentu dan dianggap sudah menjadi bagian dari bahasa tersebut. Unsur serapan yang telah terintegrasi itu kemudian disesuaikan dengan sistem atau kaidah bahasa penerima. Unsurunsur bahasa lain itu tidak lagi dianggap sebagai unsur pinjaman atau pungutan, tetapi sudah dianggap sebagai bagian dari unsur bahasa penerima.

Ukuran yang digunakan untuk menentukan keintegrasian unsur serapan suatu bahasa adalah kamus (Suandi, 2014:126). Apabila suatu unsur serapan atau interferensi dari suatu bahasa sudah dicantumkan dalam kamus bahasa penerima, dapat dikatakan unsur itu sudah terintegrasi. Tetapi, jika unsur tersebut belum tercantum dalam kamus bahasa penerima, unsur itu belum bisa dikatakan terintegrasi. Kosakata bahasa Minangkabau dapat peneliti katakan sudah terintegrasi ke dalam bahasa Melayu Bengkulu karena kata-kata itu sudah ditemukan dalam kamus yang mereka beri nama Kamus Komunitas Belungguk Baso Bengkulu (Bengkulu Speech Comunity).

\section{Proses Integrasi Bahasa}

Proses integrasi unsur suatu bahasa ke dalam bahasa lain dapat berlangsung secara cepat dan dapat pula dalam jangka waktu yang cukup panjang. Proses integrasi akan berlangsung lebih cepat apabila bahasa sumber dengan bahasa penyerap memiliki banyak persamaan. Sebaliknya, proses integrasi akan berlangsung lambat apabila unsur serapan yang berasal dari bahasa sumber dengan bahasa penerima memiliki banyak perbedaan, baik dari sistemnya maupun kaidah-kaidahnya.

Untuk integrasi bahasa Minangkabau (BM) ke dalam bahasa Melayu Bengkulu (BMB), proses integrasi berlangsung secara cepat. Pada awalnya, seorang penutur bahasa Minangkabau menggunakan unsur bahasa Minangkabau dalam tuturannya dengan mitra tuturnya yang Melayu Bengkulu, karena dalam B1-nya unsur tersebut belum ada padanannya atau telah ada tetapi dia tidak mengetahuinya. Kemudian, unsur B-1 yang ia gunakan itu digunakan kembali oleh penutur bahasa Melayu Bengkulu. Misalnya, kata padek 'padat' (ungkapan untuk menyatakan kehebatan sesuatu/seseorang). 
Tuah Talino

Tahun XIII Volume 13 Nomor 1 Edisi 5 Juli 2019

ISSN 0216-079X

Balai Bahasa Kalimantan Barat

Pada tahap berikutnya, penerimaan dan penyerapan kosakata bahasa Minangkabau itu terjadi secara visual. Artinya, penyerapan itu dilakukan melalui bentuk tulisan dalam bahasa aslinya, kemudian bentuk tulisan itu disesuaikan dengan lafal dan ejaan dari bahasa resipien. Kata-kata yang sudah terintegrasi itu kemudian diserap menjadi bagian dari kosakata bahasa resipien. Misalnya kata kabek $(\mathrm{BM}) \rightarrow$ kbek $(\mathrm{BMB})$ 'ikat', panjek $(\mathrm{BM}) \rightarrow$ panjek $(\mathrm{BMB})$ 'panjat'.

\section{Integrasi Fonologi}

Integrasi fonologi adalah integrasi bahasa yang terjadi melalui perubahan sistem fonem suatu bahasa ke dalam sistem bahasa sasaran. Dalam mengucapkan kembali bunyi itu, dia menyesuaikannya dengan sistem bahasa sasaran. Integrasi pada tataran fonologi dapat terjadi karena adanya pengurangan, penambahan, dan perubahan fonem. Pengurangan, penambahan, dan perubahan fonem itu bisa terjadi pada posisi awal, tengah, dan akhir kata atau frasa.Integrasi secara fonologi juga dapat terjadi melalui proses penggabungan, pelesapan atau penghilangan fonem, penyisipan, asimilasi, dan desimilasi.

\section{METODE PENELITIAN}

Penelitian ini menggunakan metode kualitatif, yaitu metode penelitian yang bersifat deskriptif. Dikatakan deskriptif karena penelitian ini hanya didasarkan pada fakta atau fenomena yang ada dan secara empiris hidup pada penuturnya, sehingga hasilnya adalah perian bahasa yang mempunyai sifat pemaparan apa adanya (Sudaryanto, 1993:62). Penelitian ini berusaha menjelaskan secara mendalam integrasi fonologi bahasa Minangkabau dalam bahasa Melayu Bengkulu. Data penelitian ini yaitu berupa tuturan yang terdapat dalam grup facebook "Komunitas Belungguk Baso Bengkulu". Data diperoleh dengan menggunakan metode simak, dengan teknik dasar berupa teknik sadap. Dilanjutkan dengan teknik simak bebas libat cakap dan teknik catat. Penyimakan dilakukan dengan menyadap penggunaan bahasa dalam grup facebook "Komunitas Belungguk Baso Bengkulu".

Untuk menganalisis data digunakan metode padan intralingual, yaitu metode analisis yang dilakukan dengan cara menghubung-bandingkan unsurunsur yang bersifat lingual dalam bahasa Minangkabau dan bahasa Melayu Bengkulu. Metode ini dilanjutkan dengan teknik hubungbanding menyamakan (HBS) dan hubungbanding membedakan (HBB) (Mahsun, 2005:117--119). Hal ini dilakukan karena data yang dianalisis adalah data yang berupa kata-kata.

Selain kedua teknik di atas, metode ini memiliki satu teknik lagi, yaitu teknik hubung banding menyamakan hal pokok (HBSP), yaitu teknik yang bertujuan mencari kesamaan hal pokok dari pembedaan dan penyamaan yang dilakukan dengan menerapkan teknik HBS dan HBB, karena tujuan akhir dari banding menyamakan dan membedakan tersebut adalah menemukan kesamaan pokok di antara data yang diperbandingkan itu.

Untuk menyajikan hasil analisis data penelitian ini digunakan metode penyajian hasil analisis data secara informal dan secara formal. Metode penyajian informal adalah perumusan dengan menggunakan kata-kata biasa, termasuk penggunaan terminologi yang bersifat teknis. Metode formal adalah perumusan dengan menggunakan tanda-tanda atau lambang-lambang (Mahsun, 2005:123). 
Tuah Talino

Tahun XIII Volume 13 Nomor 1 Edisi 5 Juli 2019

ISSN 0216-079X

Balai Bahasa Kalimantan Barat

Beberapa tanda atau lambang yang digunakan antara lain tanda (/Ө/) yang digunakan untuk menunjukkan bahwa terjadi penghilangan fonem. Tanda garis miring $(/ /)$ digunakan untuk menunjukkan satuan di dalamnya adalah fonem. Tanda kurung siku ([ ]) untuk menunjukkan satuan fonetis dan untuk melambangkan bunyi tertentu yang tidak berstatus fonem, dan tanda $(\rightarrow)$ melambangkan berubah menjadi.

Selain itu, lambang-lambang yang dapat digunakan antara lain lambang huruf sebagai singkatan, yaitu BM untuk bahasa Minangkabau, dan BMB untuk bahasa Melayu Bengkulu.

\section{PEMBAHASAN}

\section{Integrasi Fonologi Bahasa Minangkabau ke dalam Bahasa Melayu Bengkulu}

Integrasi adalah diserapnya kata-kata dari satu bahasa ke dalam bahasa lain. Berdasarkan hasil analisis peneliti terhadap data yang terdapat dalam facebook Komunitas Belungguk Baso Bengkulu, ditemukan bentuk integrasi fonologi bahasa Minangkabau ke dalam bahasa Melayu Bengkulu. Integrasi bahasa Minangkabau ke dalam bahasa Melayu Bengkulu dalam bentuk fonologi yaitu berupa penghilangan fonem (pada awal, tengah, dan akhir), penambahan fonem (pada posisi awal, tengah, dan akhir) atau melalui proses perubahan fonem. Bentuk-bentuk integrasi bahasa Minangkabau ke dalam bahasa Melayu Bengkulu berupa penghilangan fonem itu misalnya fonem $/ \mathrm{a} / \mathrm{A} / \mathrm{\Theta} / \mathrm{/} / \mathrm{h} / \rightarrow / \Theta /$, baik di depan, di tengah, maupun di belakang.

\section{Penghilangan Fonem}

Penghilangan fonem merupakan proses penghilangan fonem yang seartikulasi, fonem yang sama dijadikan tidak sama. Bentuk-bentuk integrasi bahasa Minangkabau dalam bahasa Melayu Bengkulu dalam bidang fonologi berupa penghilangan/pelesapan fonem itu misalnya seperti tampak di bawah ini.

\section{a. Penghilangan Fonem di Depan}

Integrasi bahasa Minangkabau ke dalam bahasa Melayu Bengkulu dalam bentuk fonologi berupa penghilangan fonem pada posisi depan yaitu penghilangan fonem $/ \mathrm{a} / \mathrm{l} \rightarrow \mathrm{\Theta} /$ dan penghilangan $/ \mathrm{l} / \rightarrow / \Theta /$. Untuk penghilangan fonem pada posisi awal ini dapat ditampilkan pada tabel 4 di bawah ini.

Tabel 4

\begin{tabular}{|c|c|c|c|}
\hline Fonem & Kata BM & Kata BMB & BI \\
\hline /a/ menjadi / $\mathrm{O} /$ & i. $a c o k$ & cok & 'sering' \\
\hline & ii. alah & lah & 'sudah' \\
\hline & iii.antok & ntok & 'diam’ \\
\hline$/ 1 /$ menjadi / $\mathrm{\Theta} /$ & $\begin{array}{l}\text { iv. lonjak labu } \\
\text { tabanam }\end{array}$ & $\begin{array}{l}\text { onjak labu } \\
\text { tebenam }\end{array}$ & $\begin{array}{l}\text { 'lonjak labu } \\
\text { terbenam' }\end{array}$ \\
\hline
\end{tabular}

Pada data tabel (4) di atas, terdapat integrasi fonologi bahasa Minangkabau ke dalam bahasa Melayu Bengkulu melalui penghilangan fonem. Penghilangan fonem terdapat pada awal kata, yaitu fonem $/ a / \rightarrow / \Theta /$. Sebagai contoh dapat peneliti kemukakan misalnya kata [acok] $(\mathrm{BM}) \rightarrow[\mathrm{cok}](\mathrm{BMB})$ 'sering'; [alah] $(\mathrm{BM}) \rightarrow[l a h](\mathrm{BMB})$ 'telah' atau 'sudah'; dan [antok] $(\mathrm{BM}) \rightarrow[$ ntok $](\mathrm{BMB})$ 'sering'. Pemakaiannya dalam kalimat misalnya. 
Tuah Talino

Tahun XIII Volume 13 Nomor 1 Edisi 5 Juli 2019

ISSN 0216-079X

Balai Bahasa Kalimantan Barat

i. Cok nian kenai berang. Ditakut-takuti, dikeceknyolah, "Klak kamu cacingan." 'Sering sekali kena marah. Ditakut-takuti, dikatakannyalah, "Nanti kamu cacingan."

ii. La jadi kau masak ikan puyu tadi?

'Sudah jadi kau masak ikan betok tadi?'

iii.Mengapo tobo kitoko ntok segalo?

Mengapa teman-teman kita diam semua?'

Penghilangan fonem pada posisi awal kata yang lain adalah/1/ $\rightarrow / \Theta /$. Sebagai contoh misalnya kata [lonjak labu tabanam] $(\mathrm{BM}) \rightarrow$ [onjak labu tabanam] (BMB). Pemakaiannya dalam kalimat misalnya.

i. Sayo jugo dak suko nengoknyo, serupo onjak labu tebenam.

'Saya juga tidak suka melihatnya, seperti lonjak labu tenggelam.'

\section{b. Penghilangan Fonem di Tengah}

Integrasi bahasa Minangkabau ke dalam bahasa Melayu Bengkulu dalam bentuk fonologi berupa penghilangan fonem pada posisi tengah yaitu penghilangan fonem $/ \mathrm{a} / \mathrm{H} / \mathrm{\Theta} / \mathrm{h} / \mathrm{h} / \rightarrow / \mathrm{O} / \mathrm{h} / \mathrm{i} / \rightarrow / \Theta /$, dan $/ \mathrm{h} / \rightarrow / \Theta /$. Untuk penghilangan fonem $/ \mathrm{a} / \rightarrow / \Theta /$ pada posisi tengah ini dapat ditampilkan pada tabel 5 di bawah ini.

Tabel 5

\begin{tabular}{|c|c|c|c|}
\hline Fonem & Kata BM & Kata BMB & BI \\
\hline$/ \mathrm{a} /$ menjadi $/ \Theta /$ & i. kanai & knai & 'kena' \\
\hline & ii. pakok talingo & pkok telingo & 'tutup kuping' \\
\hline & iii. jagok & jgok & 'jago'; pintar' \\
\hline & iv. buliah & bulih & 'boleh' \\
\hline & v. jariang & jering & 'jengkol' \\
\hline
\end{tabular}

Pada data tabel 5 di atas, integrasi bahasa Minangkabau ke dalam bahasa Melayu Bengkulu terjadi melalui penghilangan fonem pada posisi tengah kata, yaitu fonem/a/ $\rightarrow / \Theta /$. Sebagai contoh dapat peneliti kemukakan misalnya kata [kanai $](\mathrm{BM}) \rightarrow[$ knai $](\mathrm{BMB})$ 'kena', [pakok talingo $(\mathrm{BM}) \rightarrow[$ pkok telingo $]$ $(\mathrm{BMB})$ 'tutup telinga', [jagok] $(\mathrm{BM}) \rightarrow$ [jgok] (BMB) 'jago', [mancaliak] (BM) $\rightarrow$ [mencelik] (BMB) 'melihat', [buliah] (BM) $\rightarrow$ [bulih] (BMB) 'boleh', dan [jariang] $\rightarrow$ [jering] (BMB) 'jengkol'. Pemakaiannya dalam kalimat misalnya.

i. Jangan diknaikan ke air, klak mlekang lemnyo.

ii. Tiok ari gaek koh main dom, knai jepit manjang pkok telingonyo.

iii. Ruponyo inga kojgok nian main palak babi.

iv. Kalu idak tu, gerume muncungnyo. Buli nyo jero

v. Ado nang ndak dak sanak, jering sayo sedang lebek nian ko na.

Penghilangan fonem /a/ menjadi / $\Theta /$ pada posisi tengah yang lain dapat peneliti kemukakan pada tabel 6 di bawah ini.

Tabel 6

\begin{tabular}{|l|l|l|l|}
\hline \multicolumn{1}{|c|}{ Fonem } & \multicolumn{1}{|c|}{ Kata BM } & \multicolumn{1}{c|}{ Kata BMB } & \multicolumn{1}{c|}{ BI } \\
\hline$/$ a/ menjadi $/ \Theta /$ & i. aniang & aning & 'diam' \\
\hline & ii. bunduang & bundung & 'sumpah serapah' \\
\hline & iii. anduang & andung & 'nenek' \\
\hline & iv. gapuak & gepuk & 'gemuk' \\
\hline
\end{tabular}




\begin{tabular}{|l|l|l|l|}
\hline & v. takantuak & tkantuk & 'terkantuk' \\
\hline & vi. salero & slero & 'selera' \\
\hline
\end{tabular}

Contoh pemakaiannya dalam kalimat.

i. Iko sayo ado, aning ajo di siko Dang.

ii. Ado lagi bundung aus. Ado dak yang tau retinyo?

iii. Dang, Odang, Donga, Inga,Dodo, Cukdo, Uncu, Andung, Datuk, Endek, Ande.

iv. Iko panggilan betutur kito di Bengkulu. Apolagi dak?

v. Alangkah gepuknyo lanang tu dak, Ciknga?

vi. La tkantuk mato ambo ko. Ambo ndak tiduk dulu lah.

vii. Mela sanak kito melepehkan slero ke rumah makan tu.

Penghilangan fonem pada posisi tengah juga terjadi pada fonem $/ \mathrm{n} / \rightarrow / \Theta /$. Hal ini dapat dilihat pada tabel 7 di bawah ini.

Tabel 7

\begin{tabular}{|c|l|l|l|}
\hline \multicolumn{1}{|c|}{ Fonem } & \multicolumn{1}{c|}{ Kata BM } & \multicolumn{1}{c|}{ Kata BMB } & \multicolumn{1}{c|}{ BI } \\
\hline$/ \mathrm{n} /$ menjadi /O/ & i. $\quad$ nyanyuk & nyayuk & 'pikun' \\
\hline & ii. $\quad$ indak & idak & 'tidak' \\
\hline
\end{tabular}

Pada kata tabel 7 di atas, terjadi penghilangan fonem pada posisi tengah kata, huruf $/ \mathrm{n} / \rightarrow / \Theta /$, yaitu pada kata [nyanyuk] $(\mathrm{BM}) \rightarrow$ [nyayuk] (BMB) 'pikun', dan pada kata [indak] (BM) $\rightarrow$ [idak] (BMB) 'tidak'. Pemakaiannya dalam kalimat misalnya.

i. Tambah nyayuk bae lanang sikok tu.

ii. Idak apo-apo. Kau baelah.

Penghilangan fonem pada posisi tengah kata yang lain adalah fonem /i/ $\rightarrow$ $/ \Theta /$. Hal ini dapat dilihat pada tabel 8 di bawah ini.

Tabel 8

\begin{tabular}{|c|c|l|l|}
\hline Fonem & Kata BM & Kata BMB & BI \\
\hline$/ \mathrm{i} /$ menjadi $/ \Theta /$ & cik inan & cik nan & 'ingin sesuatu' \\
\hline
\end{tabular}

Pemakaiannya dalam kalimat misalnya.

Cik nan punan nian sayo ko, besok ndak pai Jumat pake selop jepang.

'Ingin sekali saya ini, besok mau salat Jumat pakai sendal jepit.'

Penghilangan fonem pada posisi tengah kata juga terjadi pada fonem $/ \mathrm{h} /$ yang berubah menjadi / $/$. Hal ini dapat dilihat pada tabel 9 di bawah ini.

Tabel 9

\begin{tabular}{|c|c|c|c|}
\hline Fonem & Kata BM & Kata BMB & BI \\
\hline$/ \mathrm{h} /$ menjadi $/ \Theta /$ & palapeh salero & plepe slero & 'boleh ikut' \\
\hline & ii. $\quad$ bakasih sayang & bekasi sayang & 'berkasih sayang' \\
\hline
\end{tabular}

Contoh pemakaiannya dalam kalimat.

i. Di Jawa idak ado nang bejagal iko sanak, terpakso sayo tanam sendiri. Plepe slero plepe rindu. 
Tuah Talino

Tahun XIII Volume 13 Nomor 1 Edisi 5 Juli 2019

ISSN 0216-079X

Balai Bahasa Kalimantan Barat

ii. Dulu kito berambut panjang kini lah berambut jejak bau, dulu kita bekasi sayang kini ko cicak idak tau.

\section{c. Penghilangan Fonem di Belakang}

Integrasi bahasa Minangkabau ke dalam bahasa Melayu Bengkulu melalui penghilangan fonem pada posisi belakang kata yang dapat peneliti deskripsikan adalah seperti tampak pada tabel 10 di bawah ini.

Tabel 10

\begin{tabular}{|c|c|c|c|}
\hline \multirow{7}{*}{$\begin{array}{c}\text { Fonem } \\
/ \mathrm{h} / \text { menjadi } / \Theta /\end{array}$} & Kata BM & Kata BMB & BI \\
\hline & i. juwadah & juwada & 'hidangan' \\
\hline & ii.parancah & perenca & 'pencampur' \\
\hline & iii.melah & mela & 'ayolah' \\
\hline & iv.bareh & bere & 'beras' \\
\hline & v. kanai piyuah & kenai piyu & 'kena cubit' \\
\hline & vi. garumeh & gerume & 'cakar' \\
\hline
\end{tabular}

Pada tabel 10 di atas terlihat adanya integrasi bahasa Minangkabau ke dalam bahasa Melayu Bengkulu melalui penghilangan fonem pada posisi belakang kata, yaitu pada kata [juwadah] $(\mathrm{BM}) \rightarrow$ [juwada] (BMB) 'hidangan', [parancah] $(\mathrm{BM}) \rightarrow[$ prenca $](\mathrm{BMB})$ 'campuran', [melah $](\mathrm{BM}) \rightarrow[$ mela $]$ (BMB) 'ayolah', $[$ ateh $](\mathrm{BM}) \rightarrow$ [ate $]$ 'atas', [maleh] $(\mathrm{BM}) \rightarrow$ [male] (BMB) 'malas', [bareh] $(\mathrm{BM}) \rightarrow$ [bere $]$ (BMB) 'beras', [kanai piyuah] $(\mathrm{BM}) \rightarrow$ [kenai piyua $]$ (BMB) 'kena cubit', dan [garumeh] $(\mathrm{BM}) \rightarrow$ [grume $(\mathrm{BMB})$ 'cakaran'

Contoh pemakaiannya dalam kalimat.

i. Marola adik sanak kalu ndak ngawankan ngopi petangko lawan nyo kek juada koa.

'Marilah adik/saudara, kalau mau menemani minum kopi sore ini, lawannya kue ini.'

ii. Jering mudo dekek perenca bagar hiu.

'Jengkol muda, sebagai temannya gulai hiu.'

iii.Mela kito pai ke tempek tino tu.

'Ayolah kita pergi ke tempat perempuan itu.'

iv. Kito buek idak bentuk lupis. Bahan mbueknyo masih samo, bere pulut,gulo merah,kelapo parut.

'Kita buat tidak seperti lupis. Bahan untuk membuatnya masih sama, beras ketan, gula merah, dan kelapa parut.'

v. Sakit nian oi kalo la kenai piyu tu, apolagi pao.

'Sakit sekali kalau kena cubit itu, apalagi paha.'

vi. Kalu idak tu, gerume muncungnyo, buli nyo jero.

'Kalau tidak, cakar mulutnya, biar dia kapok.'

\section{Penambahan Fonem}

Bentuk integrasi secara fonologi selanjutnya yaitu integrasi fonologi yang terjadi melalui penambahan fonem, baik pada posisi tengah maupun akhir. Bentuk-bentuk integrasi bahasa Minangkabau ke dalam bahasa Melayu Bengkulu secara fonologi berupa penambahan fonem yang ditemukan dari bahasa 
Tuah Talino

Tahun XIII Volume 13 Nomor 1 Edisi 5 Juli 2019

ISSN 0216-079X

Balai Bahasa Kalimantan Barat

Minangkabau ke dalam bahasa Melayu Bengkulu itu adalah seperti tampak di bawah ini.

\section{a. Penambahan Fonem pada Posisi Tengah}

Integrasi bahasa Minangkabau secara fonologi dengan cara penambahan fonem pada posisi tengah dalam bahasa Melayu Bengkulu misalnya seperti tampak pada tabel 11 di bawah ini.

Tabel 11

\begin{tabular}{|c|l|l|l|}
\hline Fonem & \multicolumn{1}{|c|}{ Kata BM } & \multicolumn{1}{c|}{ Kata BMB } & \multicolumn{1}{c|}{ BI } \\
\hline$/ \Theta /$ menjadi $/ \mathrm{r} /$ & taingek & taringek & 'teringat' \\
\hline$/ \Theta /$ menjadi $/ \mathrm{g} /$ & angik & anggit & $\begin{array}{l}\text { 'bau apik', spt bau } \\
\text { wereng coklat }\end{array}$ \\
\hline
\end{tabular}

Kata [taingek] dalam bahasa Minangkabau telah terintegrasi ke dalam bahasa Melayu Bengkulu melalui penambahan fonem pada posisi tengah kata menjadi [taringek], yang berarti 'teringat'. Begitu juga kata [angik] (BM) telah terintegrasi ke dalam bahasa Melayu Bengkulu melalui penambahan fonem /g/ menjadi [anggik], yang berarti 'bau apik'.

Contoh integrasi bahasa Minangkabau secara fonologi dengan cara penambahan fonem pada posisi tengah dalam bahasa Melayu Bengkulu misalnya seperti tampak pada kalimat di bawah ini.

i. Idak teringek lagi ambo kek lanang tu.

'Saya tidak ingat lagi sama laki-laki itu.'

ii. Bau apolah nang anggit ko ndak Ciknga?

'Bau apalah yang busuk ini ya Ciknga?'

\section{b. Penambahan Fonem pada Posisi Akhir}

Integrasi bahasa Minangkabau ke dalam bahasa Melayu Bengkulu tidak hanya terjadi melalui penambahan fonem pada posisi tengah kata, tetapi juga terjadi melaui penambahan fonem pada posisi akhir kata,yaitu fonem $/ 1 /, / r /$, dan /g/. Hal ini dapat dilihat pada tabel 12 di bawah ini.

Tabel 12

\begin{tabular}{|l|l|l|l|}
\hline Fonem & Kata BM & Kata BMB & BI \\
\hline$/ \Theta /$ menjadi /l/ & mada & madal & 'keras kepala'; 'nakal' \\
\hline & bajaga & bejagal & 'berjualan' \\
\hline$/ \Theta /$ menjadi /r/ & malala & melalar & 'keluyuran' \\
\hline$/ \Theta /$ menjadi /g/ & nan & nang & 'yang' \\
\hline
\end{tabular}

Kata [mada], [bajaga], [malala], dan [nan] dalam bahasa Minangkabau telah terintegrasi ke dalam bahasa Melayu Bengkulu melalui proses penambahan fonem /l/, /r/, dan /g/ pada posisi akhir kata, menjadi kata [madal], [bejagal], [melalar], dan [nang]. Untuk pemakaiannya dalam kalimat dapat dilihat pada contoh di bawah ini.

i. Madal nian kamu orang. 'Keras kepala kau ini.'

ii. Andung la melalar dak semenggah

'Nenek pergi keluyuran ke mana-mana.'

iii. Idak pacak ngecek lagi, nang sebuah iko lemak nian sanak.

'Tak bisa ngomong lagi, yang satu ini enak sekali.' 


\section{Perubahan Fonem}

Sementara bentuk-bentuk integrasi bahasa Minangkabaudalam bahasa Melayu Bengkulu dalam bidang fonologi berupa perubahan fonem adalah fonem /a/ berubah menjadi /e/, /u/ $\rightarrow$ /o/, /u/ $\rightarrow$ /e/, /uik/ $\rightarrow$ /ut/, /ua/ $\rightarrow$ /ur/, dan /ik/ $\rightarrow$ /it/. Perubahan fonem itu bisa pada posisi awal, tengah, dan akhir kata. Bentukbentuk integrasi bahasa Minangkabau dalam bahasa Melayu Bengkulu dalam bidang fonologi yang ditemukan berupa perubahan fonem /a/ menjadi /e/ misalnya seperti tampak di bawah ini.

\section{/a/ menjadi /e/}

$\begin{array}{lll}\text { baligat }(\mathrm{BM}) & \text { beligat }(\mathrm{BMB}) & \text { 'cekatan' } \\ \text { mancalik }(\mathrm{BM}) & \text { mencelik }(\mathrm{BMB}) & \text { 'melihat' } \\ \text { talambek }(\mathrm{BM}) & \text { telambek }(\mathrm{BMB}) & \text { 'terlambat' } \\ \text { maliyek }(\mathrm{BM}) & \text { meliyek }(\mathrm{BMB}) & \text { 'melihat' } \\ \text { mangango }(\mathrm{BM}) & \text { mengango }(\mathrm{BMB}) & \text { 'menganga' } \\ \text { marapek }(\mathrm{BM}) & \text { merapek }(\mathrm{BMB}) & \text { 'merapat' } \\ \text { maratok }(\mathrm{BM}) & \text { meratok }(\mathrm{BMB}) & \text { 'maratap' } \\ \text { tampek }(\mathrm{BM}) & \text { tempek }(\mathrm{BMB}) & \text { 'tempat' } \\ \text { maraso }(\mathrm{BM}) & \text { meraso }(\mathrm{BMB}) & \text { 'merasa' } \\ \text { salemo }(\mathrm{BM}) & \text { selemo }(\mathrm{BMB}) & \text { 'selesma' } \\ \text { marando }(\mathrm{BM}) & \text { merando }(\mathrm{BMB}) & \text { 'menjanda' } \\ \text { maratok }(\mathrm{BM}) & \text { meratok }(\mathrm{BMB}) & \text { 'meratap' } \\ \text { gadang }(\mathrm{BM}) & \text { gedang }(\mathrm{BMB}) & \text { 'besar' } \\ \text { kanai }(\mathrm{BM}) & \text { kenai }(\mathrm{BMB}) & \text { 'kena' } \\ \text { tapanggang }(\mathrm{BM}) & \text { tepanggang }(\mathrm{BMB}) & \text { 'terbakar' } \\ \text { takok uwok }(\mathrm{BM}) & \text { tekok } \text { uwok }(\mathrm{BMB}) & \text { 'teka-teki' } \\ \text { pakau }(\mathrm{BM}) & \text { pekau }(\mathrm{BMB}) & \text { 'bingung' } \\ \text { Contoh pemakaiannya dalam kalimat misalnya, }\end{array}$

i. Wai lapar mencelik gulai ko e.

ii. Baru ndak seto, telambek dak sanak?

iii. Marolah merapek sanak..kito makan sesamo-samo.

iv. Kalau dak sehat minumlah jamu, jangan lupo makan ketupek. Kalau donga/inga dak betamu, sayo siap sedio tempek.

'Kalau mau sehat, minumlah jamu, jangan lupa makan ketupat. Kalau Ibu/Bapak mau bertamu, saya siap menyediakan tempat.

v. Makan slengek suko nian,tapi teselek tulang idak lemak nian.

/u/ menjadi /o/

/u/ menjadi /e/ urang gaek $(\mathrm{BM}) \quad$ orang gaek $(\mathrm{BMB}) \quad$ 'orang tua'

$$
\text { gulamo }(\mathrm{BM}) \quad \text { gelamo }(\mathrm{BMB}) \quad \text { 'ikan gelamo' }
$$

\section{/uik/ menjadi /ut/}

Misalnya. Ikan beledang ikan gelamo

kambuik (BM) kambut (BMB) 'tas dari anyaman pandan'

sakauik(BM) sekaut(BMB) 'segenggam'

lacuik (BM) lecut(BMB) 'lecut'

Misalnya. Lecut itu belahan bilah bambu atau rotan ikur pari dipegang lalu dipukulkan. 


\section{/ua/ menjadi /ur/}

maliyua $(\mathrm{BM})$

gabua(BM)

malunjua $(\mathrm{BM})$

meliyur (BMB) 'meludah'

tabang ambua $(\mathrm{BM})$

gebur (BMB) 'ikan gebur'

Misalnya. Ngapo pulo kamu meliyur di situ Cik?

'Kenapa kamu meludah di situ?'

Berapo gebur sekilo Donga?

'Berapa gebur sekilo, Donga?'

Aku nak melunjurkan kakiku dulu lah.

'Saya mau melunjurkan kaki dulu ya.'

Tobo kito ko la pening kek gempo ko, la raso dak tebang ambur tobo ko, Donga.

'Saudara kita ini sudah pusing sama gempa ini, sudah mau

\section{/ik/ menjadi /it/} berhamburan saudara kita itu.'

Sebagaimana halnya bahasa Minangkabau, untuk kata yang berakhir dengan /i?/ akan berubah menjadi /it/ dalam bahasa Indonesia, misalnya [sakik] 'sakit', [bangkik] 'bangkit', begitu juga halnya dengan bahasa Melayu Bengkulu yang merupakan integrasi dari bahasa Minangkabau. Untuk kata yang berakhir dengan /ik/ dalam bahasa Minangkabau akan berubah menjadi /it/ dalam bahasa Melayu Bengkulu. Bedanya, kata-kata itu dicoba dijadikan bahasa Indonesia, akan tetapi usahanya mengindonesiakan kata-kata itu gagal, karena tidak sesuai dengan bentuk bahasa Indonesia yang sebenaranya. Hal ini dapat dilihat pada contoh di bawah ini.

$\begin{array}{lll}\text { tapalancik }(\mathrm{BM}) & \text { teplancit }(\mathrm{BMB}) & \text { 'membersit' } \\ \text { bakanyik }(\mathrm{BM}) & \text { bekenyit }(\mathrm{BMB}) & \text { 'berkerut' } \\ \text { angik }(\mathrm{BM}) & \text { anggit }(\mathrm{BMB}) & \text { 'angit' }\end{array}$

Pemakaiannya dalam kalimat misalnya.

Aponyo yang teplancit tu cik...mako nyo ati2..dikit..

Ngapo pagi-pagi lah bekenyit kening kau?

Alangka anggitnyo bau wereng ko eh!

\section{PENUTUP}

Berdasarkan hasil analisis terhadap data, dapat peneliti simpulkan bahwa memang terdapat integrasi bahasa Minangkabau ke dalam bahasa Melayu Bengkulu. Integrasi itu terjadi dalam bentuk integrasi fonologi. Integrasi fonologi terjadi melalui penghilangan fonem, penambahan fonem, dan perubahan fonem, baik pada posisi awal, tengah, maupun pada posisi akhir. Integrasi fonologi melalui penghilangan fonem yang ditemukan yaitu $/ \mathrm{a} / \rightarrow / \Theta /$ dan $/ 1 / \rightarrow / \Theta /$. Misalnya pada kata $[$ acok $](\mathrm{BM}) \rightarrow[$ cok] $(\mathrm{BMB})$ 'sering'; [alah] $(\mathrm{BM}) \rightarrow[l a h]$ $(\mathrm{BMB})$ 'telah' atau 'sudah'; dan [antok] $(\mathrm{BM}) \rightarrow[$ ntok $](\mathrm{BMB})$ 'diam'.

Penghilangan fonem pada posisi tengah yaitu penghilangan fonem $/ \mathrm{a} / \rightarrow$ $/ \Theta /, / \mathrm{n} / \rightarrow / \Theta /, / \mathrm{i} / \rightarrow / \Theta /$, dan $/ \mathrm{h} / \rightarrow / \Theta /$. Misalnya kata $[$ kanai $](\mathrm{BM}) \rightarrow[$ knai $]$ $(\mathrm{BMB})$ 'kena', [pakok talingo $](\mathrm{BM}) \rightarrow$ [pkok telingo $](\mathrm{BMB})$ 'tutup telinga', [jagok] $(\mathrm{BM}) \rightarrow[$ jgok] $(\mathrm{BMB})$ 'jago', [mancaliak $(\mathrm{BM}) \rightarrow[$ mencelik] $(\mathrm{BMB})$ 
'melihat', [buliah] $(\mathrm{BM}) \rightarrow$ [bulih] $(\mathrm{BMB})$ 'boleh', dan [jariang] $\rightarrow$ [jering] (BMB) 'jengkol'.

Penghilangan fonem pada posisi belakang kata, yaitu penghilangan $/ \mathrm{h} / \rightarrow$ $/ \Theta /$. Misalnya pada kata [juwadah] $(\mathrm{BM}) \rightarrow$ [juwada] (BMB) 'hidangan', $[$ parancah $](\mathrm{BM}) \rightarrow[$ prenca $](\mathrm{BMB})$ 'campuran', [pitih] $(\mathrm{BM}) \rightarrow[$ piti $](\mathrm{BMB})$ 'uang', [melah $](\mathrm{BM}) \rightarrow[$ mela $]$.

Integrasi bahasa Minangkabau secara fonologi dengan cara penambahan fonem pada posisi tengah dalam bahasa Melayu Bengkulu yaitu $/ \Theta / \rightarrow / \mathrm{r} /$ dan $/ \Theta /$ $\rightarrow / g /$.Integrasi melalui penambahan fonem pada posisi akhir kata,yaitu fonem /1/, /r/, dan /g/.Misalnya kata [madal], [bejagal], [melalar], dan [nang].

Bentuk-bentuk integrasi bahasa Minangkabau dalam bahasa Melayu Bengkulu dalam bidang fonologi berupa perubahan fonem adalah fonem /a/ berubah menjadi /e/, /u/ $\rightarrow / \mathrm{o} /, / \mathrm{u} / \rightarrow / \mathrm{e} /$, uik/ $\rightarrow$ /ut/, /ua/ $\rightarrow / \mathrm{ur} /$, dan /ik/ $\rightarrow$ /it/ dalam bahasa Melayu Bengkulu.

\section{DAFTAR PUSTAKA}

Beardsmore, H.B. (1982). Bilingualism: Basic Principles. Vrije Universiteit Brussel.

Chaer, Abdul dan Leoni Agustina. 1995. Sosiolinguistik Perkenalan Awal. Jakarta: Rineka Cipta. (2010). Sosiolinguistik Perkenalan Awal. Jakarta: Rineka Cipta.

Khak, Abdul, dkk. (1985). Interferensi Gramatika Bahasa Indonesia dalam Bahasa Jawa. Jakarta. Pusat Pembinaan dan Pengembangan Bahasa.

Kridalaksana, Harimurti. (1998). Introduction to Word Formation and Word Classes. Jakarta. Universitas Indonesia.

Maksum, (2005). Metode Penelitian Bahasa, Tahapan Strategi, Metode, dan Tekniknya. Jakarta: Rajawali Pers.

Nababan, P.W.J. (1984). Sosiolinguistik. Jakarta: Gramedia.

Suandi, I Nengah. (2014). Sosiolinguistik. Yogyakarta: Graha Ilmu.

Saharuddin. (2016). Interferensi Bahasa Bugis Terhadap Penggunaan Bahasa Indonesia di Pasar Tradisional Desa Sioyong, Kabupaten Donggala.eJurnal Bahasantodea,

Volume 4 Nomor 1, Januari 2016 hlm 68-78

Sudaryanto. (1993). Metode dan Aneka Teknik Penelitian Bahasa. Yogyakarta: Duta Wacana University Press.

Suwito. (1988). Sosiolinguistik. Surakarta: UNS Press. 